\title{
Specific Detection of the Root-Lesion Nematode Pratylenchus scribneri Using Conventional and Real-Time PCR
}

\author{
Danqiong Huang and Guiping Yan, Department of Plant Pathology, North Dakota State University, Fargo 58108-6050
}

\begin{abstract}
Pratylenchus scribneri is a plant-parasitic root-lesion nematode causing economic damage to various crops worldwide. Identifying root-lesion nematodes to species using traditional morphological methods is an arduous task requiring extensive training on nematode taxonomy and years of experience. Thus, molecular methods for $P$. scribneri detection and identification were developed. Conventional and real-time polymerase chain reaction (PCR) assays with new species-specific primers were used in this study, which exclusively amplified DNA of $P$. scribneri but not DNA from other Pratylenchus spp. or non-Pratylenchus spp. tested. Compared with conventional PCR that was able to detect an equivalent

to 1/4 of the DNA of a single nematode, real-time PCR was more sensitive and could amplify an equivalent to $1 / 128$ of the DNA of one nematode. Both conventional and real-time PCR assays successfully identified $P$. scribneri and distinguished it from P. penetrans and P. neglectus isolated from field samples collected from various locations in North Dakota and Minnesota. The Blast-search based on the sequence information confirmed the reliability of the PCR assays for species identification. This is the first report of $P$. scribneri identification using a real-time PCR assay. The developed PCR assays are suitable for use in diagnostic laboratories and detection of field infestations with this nematode species.
\end{abstract}

Root-lesion nematodes (Pratylenchus spp.) are among the top 10 most damaging plant-parasitic nematodes and include over 70 species that are found worldwide in a wide variety of crops (Jones et al. 2013; Jones and Fosu-Nyarko 2014). Pratylenchus scribneri is known to be an economic pathogen to a wide range of crops, including barley, maize, soybean, potato, sugar beet, broccoli, tomato, onion, strawberry, and peach (Castillo and Volvas 2007). The infestation of $P$. neglectus in a wheat field reduced the yield up to $36 \%$ (Smiley et al. 2005). P. penetrans induced tuber lesions and reduced the yield of potato by $50 \%$ in the affected field (Holgado et al. 2009). Crop rotation and plant resistance are the most commonly used management strategies for these nematode diseases. However, the choice of crops for rotation requires extra diagnostic data of plant parasitic nematode species in a field, because only a few plant species or cultivars are reported to be immune or to have some level of resistance to Pratylenchus spp. (Castillo and Volvas 2007).

The species identification of Pratylenchus spp. can be difficult because there are frequently mixed populations in the same field (Castillo and Volvas 2007). Normally, the diagnostics of Pratylenchus spp. relied on morphometric features of adults, including the number of lip annuli, stylet length, postuterine sac length, vulva position, and body length (Castillo and Volvas 2007). However, some Pratylenchus spp. look similar in morphology under a dissecting microscope, without distinct morphometric diagnosis features. Therefore, a simple, rapid, and reliable diagnostic method for Pratylenchus sp. identification is needed. DNA-based techniques have been used previously to discriminate species of plant-parasitic nematodes (Oliveira et al. 2011; Yu et al. 2012). Pinochet et al. (1994) reported the use of random amplified polymorphic DNA polymerase chain reaction (PCR) analysis to differentiate isolates of $P$. vulnus. Since then, many studies have been done for molecular identification of Pratylenchus spp. by restriction fragment length polymorphisms,

Corresponding author: G. P. Yan; E-mail: guiping.yan@ndsu.edu

*The $\boldsymbol{e}$-Xtra logo stands for "electronic extra" and indicates that one supplementary table and three supplementary figures are published online.

Accepted for publication 10 October 2016.

() 2017 The American Phytopathological Society sequencing, or species-specific PCR (Al-Banna et al. 2004; Machado et al. 2007; Uehara et al. 1998a,b, 1999; Waeyenberge et al. 2000, 2009; Yan et al. 2008, 2016b,c). Among them, the species-specific PCR is simple and has relatively lower cost. The species-specific PCR primers were designed based on the sequence information of ribosomal DNA (e.g., 28S rRNA and internal transcribed spacer [ITS] rDNA), mitochondrial DNA (e.g., cytochrome c oxidase gene), and other specific genes (e.g., $\beta$-1,4-endoglucanase gene and major sperm protein gene) (Castillo and Volvas 2007). In the molecular detection of $P$. penetrans, specific primer sets designed from ITS rDNA, 28S rRNA, and the $\beta$-1,4-endoglucanase gene, including PP1/PP2, NEGf/NEGr, PpenA/AB28, PPEN/D3B, PP5, and PpenMFor/PpenMRev, were reported to successfully identify $P$. penetrans through regular PCR, duplex PCR, or real-time PCR (Al-Banna et al. 2004; Mekete et al. 2011; Mokrini et al. 2013; Sato et al. 2007; Uehara et al. 1998a; Waeyenberge et al. 2009). AlBanna et al. (2004) reported that PNEG/D3B designed from the D2D3 expansion region of $28 \mathrm{~S}$ rRNA discriminated $P$. neglectus from $P$. brachyurus, $P$. scribneri, $P$. penetrans, $P$. thornei, and $P$. vulnus. The primer set (PNEG-F1/D3B5) modified by Yan et al. (2008) could also specifically identify $P$. neglectus in soil by conventional PCR. Subsequently, Yan et al. (2013b) developed a real-time PCR assay using primer set Pn-ITS-F2/Pn-ITS-R2 designed from ITS rDNA to detect and quantify $P$. neglectus directly from soil. Two sets of primers, PSCR/D3B (Al-Banna et al. 2004) from D2-D3 of 28S rRNA and PSC3 (Mekete et al. 2011) from ITS rDNA, were also reported for $P$. scribneri identification by conventional PCR. Moreover, other species-specific primers were reported for detection of $P$. coffeae, P. loosi, P. brachyurus, $P$. crenatus, $P$. zeae, P. thornei, and P. vulnus (Al-Banna et al. 2004; Machado et al. 2007; Uehara et al. 1998b; Waeyenberge et al. 2009; Yan et al. 2012).

Previously, $P$. scribneri and $P$. neglectus were reported in North Dakota and $P$. scribneri, $P$. neglectus, and $P$. penetrans were found in Minnesota, according to the data of morphological measurements and sequence information of 28S rRNA or ITS rDNA (Crow and MacDonald 1978; Taylor and Schleder 1959; Taylor et al. 1958; Yan et al. 2016b,c). Preliminary screening of the published primers for identifying these three Pratylenchus spp. collected from North Dakota and Minnesota suggested that $P$. neglectus could be successfully distinguished from $P$. penetrans and $P$. scribneri by PCR with primer sets PNEG-F1/D3B5 (Yan et al. 2008) and Pn-ITS-F2/Pn-ITS-R2 (Yan et al. 2013b). Similarly, P. penetrans could be distinguished from $P$. neglectus and P. scribneri by conventional PCR with primer PP5 
(Mekete et al. 2011). However, PSCR/D3B and PSC3, reported to be specific for P. scribneri (Al-Banna et al. 2004; Mekete et al. 2011), failed to specifically detect the $P$. scribneri populations from our region. Hence, PCR assays with new species-specific primers are required for identification of $P$. scribneri to facilitate the diagnostic process of this nematode in this area. The objectives of this study were to develop rapid and reliable assays for the specific detection of $P$. scribneri from other Pratylenchus spp. using conventional PCR, to test the ability of specific primers for quantitative detection of this nematode species using real-time PCR, and to evaluate the capability of the assays used for detecting this nematode extracted from infested field samples.

\section{Materials and Methods}

Nematode isolation and DNA extraction. Nematodes were extracted from $200 \mathrm{~g}$ of soil using sieving and sucrose-centrifugation methods (Jenkins 1964; Plaisance and Yan 2015). Root-lesion nematodes were collected based on their morphological features (Castillo and Volvas 2007). DNA was extracted from nematodes using the Proteinase K method, as described by Kumari and Subbotin (2012). Briefly, the nematode suspension containing chopped nematode pieces $(10 \mu \mathrm{l})$ was pipetted into a 0.5 - $\mathrm{ml}$ sterile centrifuge tube with $2 \mu l$ of $10 \times$ PCR buffer, $2 \mu l$ of Proteinase K $(600 \mu \mathrm{g} / \mathrm{ml})$, and $6 \mu l$ of double-distilled (dd) $\mathrm{H}_{2} \mathrm{O}$. Tubes were kept at $-20^{\circ} \mathrm{C}$ for at least $30 \mathrm{~min}$, then incubated at $65^{\circ} \mathrm{C}$ for $1 \mathrm{~h}$ followed by $95^{\circ} \mathrm{C}$ for $10 \mathrm{~min}$. The DNA suspension was stored at $-20^{\circ} \mathrm{C}$ until used for the following experiments. All DNA were independently extracted from three different individuals of each sample as three biological replicates. For 16 of the nematode DNA used as controls in this study (Table 1), the nematode species were already confirmed and DNA had already been extracted and used in two other studies to develop species-specific real-time PCR for detection of root-lesion nematode ( $P$. neglectus) and cyst nematode (Heterodera filipjevi and H. avenae) (Yan et al. 2013a,b).

Development of species-specific primers. A sequence alignment of 21 ITS rDNA from eight Pratylenchus spp., including $P$. pseudocoffeae, $P$. neglectus, $P$. penetrans, $P$. zeae, $P$. crenatus, $P$. thornei, $P$. agilis, and $P$. scribneri, was constructed using the MegAlign module of DNASTAR software (Lasergene) (Supplementary Fig. S1). The sequences with corresponding GenBank accession numbers contained seven isolates of $P$. agilis (FJ712887.1, FJ712888.1, FJ712889.1, FJ712890.1, FJ712891.1, JQ039330.1, and KC952982.1), eight isolates of P. scribneri (JX046931.1, JX046932.1, JX046933.1, JX046934.1, JX046935.1, KM094195.1, KP995312.1, and KT873860.1), and one isolate each of $P$. pseudocoffeae (LC030337.1), P. neglectus (JX046941.1), P. penetrans (FJ712976.1), P. zeae (LC030344.1), $P$. crenatus (LC030306.1), and P. thornei (FR692299.1). Two pairs of primers were designed within the diverse region of ITS rDNA among different species but within conserved regions among isolates of $P$. scribneri, using the PrimerSelect module of DNASTAR software. The specificity of primers was verified in silico using the Blast-search at the National Center for Biotechnology Information (NCBI) and results revealed no perfect match with other plantparasitic nematode sequences in GenBank (http://www.ncbi.nlm. nih.gov/). Primers were synthesized by Eurofin MWG Operon LLC (Huntsville, AL). The performance of PCR amplification with designed primers at different annealing temperature $(56,60$, and $62^{\circ} \mathrm{C}$ ) on specificity and efficiency was evaluated using DNA from $P$. scribneri, $P$. neglectus, and $P$. penetrans. The best-performing primer set, PsF7 (forward, 5'-AGTGTTGCTATAATTCATGTAA AGTTGC-3') and PsR7 (reverse, 5'-TGGCCAGATGCGATTCG AGAGGTGT-3'), with annealing temperature at $60^{\circ} \mathrm{C}$, was selected in the following experiments.

Conventional and real-time PCR assays. To check the quality of DNA used in this study, a set of universal primers (D3A/D3B) was used to amplify the D3 expansion region of $28 \mathrm{~S}$ rRNA, and the PCR amplification was accomplished as described by Yan et al. (2013a). For the conventional PCR assay using primer set PsF7/PsR7, PCR amplification was performed on Bio-Rad T100 Thermal Cycler (Bio-Rad Laboratories, Inc., Hercules, CA). The amplification conditions were denaturing for $10 \mathrm{~s}$ at $94^{\circ} \mathrm{C}(3 \mathrm{~min}$ before the first cycle), annealing for $20 \mathrm{~s}$ at $60^{\circ} \mathrm{C}$, and extension for $30 \mathrm{~s}$ at $72^{\circ} \mathrm{C}(10 \mathrm{~min}$ after the final cycle) for 35 cycles. Each PCR $(20 \mu \mathrm{l})$ consisted of $1.0 \mu \mathrm{l}$ of DNA template, $0.3 \mu \mathrm{M}$ each primer, $0.2 \mathrm{mM}$ dNTP, $1.5 \mathrm{mM} \mathrm{MgCl} 2,1 \times$ Green GoTaq Flexi buffer, and 1 U of GoTaq Flexi DNA Polymerase (Promega Corp., Madison, WI). PCR products were separated in $2 \%$ agarose gel at $100 \mathrm{~V}$ for $20 \mathrm{~min}$. The gel was visualized under UV light and images were captured using an AlphaImager Gel Documentation System (Proteinsimple Inc., Santa Clara, CA). Each individual DNA

Table 1. Isolates of Pratylenchus spp. and other nematode species used to test the specificity of primers for Pratylenchus scribneri identification using conventional and real-time polymerase chain reaction

\begin{tabular}{|c|c|c|c|c|c|}
\hline Code & Species & Host & Location & Source & Reference \\
\hline $\mathrm{Pc}^{\mathrm{a}}$ & Pratylenchus crenatus & Grass & Maryland & A. Skantar & Yan et al. (2013b) \\
\hline $\mathrm{Pz} 20^{\mathrm{a}}$ & P. zeae & Corn & North Carolina & A. Skantar & Yan et al. (2013b) \\
\hline $\mathrm{Pz} 21^{\mathrm{a}}$ & P. zeae & Spider lily & Singapore & A. Skantar & Yan et al. $(2013 a, b)$ \\
\hline $\mathrm{Pt}^{\mathrm{a}}$ & P. thornei & Wheat & Oregon & R. Smiley & Yan et al. $(2013 a, b)$ \\
\hline $\mathrm{Pn}-\mathrm{O}^{\mathrm{a}}$ & P. neglectus & Wheat & Oregon & R. Smiley & Yan et al. (2013b) \\
\hline Pn-N & P. neglectus & Wheat & North Dakota & G. Yan & Yan et al. (2016c) \\
\hline $\mathrm{Pp}^{\mathrm{a}}$ & P. penetrans & Potato & Wisconsin & A. Skantar & Yan et al. (2013b) \\
\hline $\mathrm{Pa}^{\mathrm{a}}$ & P. agilis & Corn & Maryland & A. Skantar & Yan et al. (2013b) \\
\hline Ps-p & P. scribneri & Potato & North Dakota & G. Yan & Yan et al. (2016b) \\
\hline Ps- $\mathrm{t}^{\mathrm{a}}$ & P. scribneri & Tomato & Florida & A. Skantar & Yan et al. (2013b) \\
\hline Ps-c ${ }^{a}$ & P. scribneri & Corn & Ohio & A. Skantar & Yan et al. (2013b) \\
\hline $\mathrm{Hs}$ & Heterodera schachtii & Sugarbeet & North Dakota & B. Nelson & Nelson et al. (2012) \\
\hline $\mathrm{Ht}$ & H. trifolii & $\mathrm{N} / \mathrm{A}^{\mathrm{b}}$ & Minnesota & S. Chen & $\mathrm{N} / \mathrm{A}^{\mathrm{b}}$ \\
\hline $\mathrm{Ha}^{\mathrm{a}}$ & H. avenae & Wheat & Washington & R. Smiley & Yan et al. $(2013 a, b)$ \\
\hline $\mathrm{Hf}^{\mathrm{a}}$ & H. filipjevi & Wheat & Oregon & R. Smiley & Yan et al. (2013b) \\
\hline $\mathrm{Mn}^{\mathrm{a}}$ & Meloidogyne naasi & Wheat & Oregon & A. Skantar & Yan et al. $(2013 a, b)$ \\
\hline $\mathrm{Mh}^{\mathrm{a}}$ & M. hapla & Rose & Canada & A. Skantar & Yan et al. $(2013 a, b)$ \\
\hline $\mathrm{Mi}^{\mathrm{a}}$ & M. incognita & Tomato & Maryland & A. Skantar & Yan et al. (2013a) \\
\hline Stb1 & Paratrichodorus allius & Potato & North Dakota & G. Yan & Yan et al. (2016d) \\
\hline Stb2 & P. allius & Sugarbeet & Minnesota & G. Yan & Yan et al. (2016a) \\
\hline $\mathrm{Gp}^{\mathrm{a}}$ & Globodera pallida & Potato & Idaho & A. Skantar & Yan et al. $(2013 a, b)$ \\
\hline $\mathrm{Gr}^{\mathrm{a}}$ & G. rostochiensis & Potato & New York & A. Skantar & Yan et al. $(2013 a, b)$ \\
\hline
\end{tabular}

\footnotetext{
${ }^{a}$ Nematodes that were used in other studies.
}

b No information available. 
was amplified twice independently to confirm the accuracy of PCR results.

To test whether primers could be used in real-time PCR assay for quantitative detection, a real-time PCR assay was developed. The amplification was performed on Bio-Rad CFX96 Touch Real-time PCR Detection System (Bio-Rad Laboratories, Inc.). A 12- $\mu 1$ PCR contained $1.0 \mu \mathrm{l}$ of DNA template, $0.36 \mu \mathrm{l}$ of each primer $(10 \mu \mathrm{M}), 6.0 \mu \mathrm{l}$ of SsoAdvanced Universal SYBR Green Supermix (Bio-Rad Laboratories, Inc.), and $4.28 \mu \mathrm{l}$ of $\mathrm{ddH}_{2} \mathrm{O}$. A nontemplate control, using $\mathrm{ddH}_{2} \mathrm{O}$ instead of DNA in the PCR, was run for each experiment. Amplification conditions were incubation at $95^{\circ} \mathrm{C}$ for $4 \mathrm{~min}$ and 35 cycles at $95^{\circ} \mathrm{C}$ for $10 \mathrm{~s}$ and $60^{\circ} \mathrm{C}$ for $30 \mathrm{~s}$. To evaluate the amplification specificity, melting curve analysis was performed at the end of each PCR run according to the manufacturer's recommendation. The melting curve temperature profile was generated by increasing the temperature of the reaction from 65 to $95^{\circ} \mathrm{C}$ in increments of $0.5^{\circ} \mathrm{C} /$ cycle. All DNA templates were run in triplicate. The data were analyzed using Bio-Rad CFX Manager Software V3.1. The quantification cycle value $(\mathrm{Cq})$ was determined at default settings. PCR product identity was confirmed by electrophoresis on a $2 \%$ agarose gel.

Primer specificity evaluation. The specificity of primers was evaluated using DNA from confirmed species of Pratylenchus and other nematodes (Table 1). Those nematodes were primarily from the United States but one was sourced from Canada and one from Singapore (Yan et al. 2013 a,b, 2016a,b,c,d). They included seven root-lesion nematode species (one isolate of $P$. crenatus, two isolates of $P$. zeae, one isolate of $P$. thornei, three isolates of $P$. neglectus, one isolate of $P$. penetrans, one isolate of $P$. agilis, and three isolates of $P$. scribneri), one stubby root nematode species (two isolates of Paratrichodorus allius), six cyst nematode species (one isolate each of H. trifolii, H. schachtii, H. avenae, H. filipjevi, Globodera pallida, and G. rostochiensis), and three root-knot nematode species (one isolate each of Meloidogyne naasi, M. hapla, and M. incognita).

Determination of the sensitivity of PCR assays. To investigate the minimum number of individuals of Pratylenchus scribneri that could be amplified by the conventional PCR assay, an experiment was conducted using $0.5,1,2,5$, and 10 individual nematodes, each in triplicate, revealing that target PCR products could be detected from DNA extracts of up to 0.5 individuals (Supplementary Fig. S2.). To further determine the minimum number of nematodes that could be detected using conventional PCR and real-time PCR assays as described above, sequential twofold serial dilutions of DNA extracted from two females of $P$. scribneri were used in PCR. Dilutions contained the DNA extracted from an equivalent of two nematodes down to $1 / 128$ of a nematode $(2,1,1 / 2,1 / 4,1 / 8,1 / 16,1 / 32$, $1 / 64$, and $1 / 128)$. PCR assays were run three times for each DNA dilution. To compare the detection sensitivity of conventional PCR and real-time PCR, both assays were performed on the same set of DNA dilutions with same amount of template, primer concentration, annealing temperature, and PCR cycle numbers, as described above. The sensitivity of conventional PCR detection was determined as the minimum number of nematodes producing visible amplicons on $2.0 \%$ agarose gel. In the real-time PCR assay, a standard curve was generated according to the linear regression between $\mathrm{Cq}$ value and corresponding $\log$ of the amount of $P$. scribneri individuals in the template. The amplification efficiency $(\mathrm{E})$, linear regression line, and coefficient of determination $\left(R^{2}\right)$ were generated automatically by Bio-Rad CFX Manager Software V3.1. The detection sensitivity of the real-time PCR assay was determined as the minimum number of nematodes producing a $\mathrm{Cq}$ value lower than 34 .

Identification of Pratylenchus spp. isolated from field samples using PCR assays. According to our survey conducted in 2014, rootlesion nematodes were found in North Dakota on five field crops (Yan et al. 2015). Previously, root-lesion nematodes were also reported in Minnesota (Chen et al. 2012; Crow and MacDonald 1978; Taylor and Schleder 1959; Taylor et al. 1958). To determine whether PCR assays with specific primers could be used to distinguish P. scribneri from other Pratylenchus spp. found in North Dakota and Minnesota, root-lesion nematodes were isolated from 31 soil samples collected from various fields on seven crops in North Dakota and
Minnesota. The crops were field pea, corn, wheat, barley, soybean, potato, and sugarbeet. The fields were distributed across 13 counties of North Dakota (Nelson, Ransom, Grand Forks, Sargent, Richland, Griggs, Cass, Traill, Dickey, Stutsman, Ramsey, and Wells) and two counties of Minnesota (Sherburne and Clay) (Table 2). After extraction from soil using sieving and sucrose-centrifugation methods (Jenkins 1964; Plaisance and Yan 2015), plant-parasitic nematodes were identified to genus using microscopy based on morphological features. Root-lesion nematodes were hand picked under a dissecting microscope (Zeiss stemi 305 Lab microscope; Zeiss, Oberkochen, Germany) for molecular identification. DNA was extracted from a single nematode as described above and at least three DNA were extracted. To further estimate the ability of our developed assay to detect the target nematodes from mixed nematode populations, DNA was also extracted from the nematode suspensions isolated from field samples, as described by Donn et al. (2008) and Fatima et al. (2011). Each DNA was subjected to species-specific PCR assays with primer sets PsF7/PsR7 (this study), Pn-ITS-F2/Pn-ITS-R2 (Yan et al. 2013b), and PP5 (Mekete et al. 2011) for species identification, as described by the corresponding authors.

To further study the ability of the P. scribneri-specific PCR assay to identify this nematode from DNA extracts of mixed populations of P. scribneri and other Pratylenchus spp., the conventional PCR assay was performed using DNA that was extracted from an artificial mixture of single nematodes of $P$. scribneri and $P$. neglectus; $P$. scribneri and $P$. penetrans; and $P$. scribneri, $P$. neglectus, and $P$. penetrans. The $P$. scribneri, $P$. neglectus, and $P$. penetrans nematodes were originally from soil samples F21, F12, and F3, respectively. Three DNA were extracted and each DNA was amplified twice using a species-specific PCR assay of $P$. scribneri, $P$. neglectus, and $P$. penetrans, as described above.

Confirmation of species identity by sequencing. To further confirm the reliability of PCR assays for root-lesion nematode species identification, two genomic regions were sequenced. The D2-D3 expansion region of $28 \mathrm{~S}$ rRNA was amplified by primers D2A (5'-ACAA GTACCGTGAGGGAAAGTTG-3') and D3B (5'-TCGGAAGGAAC CAGCTACTA-3'), as described by Subbotin et al. (2008). PCR products were purified by the PCR Extract Mini Kit (5 PRIME Inc., Gaithersburg, MD) and sent out for direct sequencing. The ITS region of rDNA was amplified by primers TW81 (5'-GTTTCCGTAGGTGAACCTGC$3^{\prime}$ ) and AB28 (5'-ATATGCTTAAGTTCAGCGGGT-3'), as described by Tanha Maafi et al. (2003). After purification by the PCR Extract Mini Kit, PCR products were ligated into the pGEM-T easy vector (Promega Corp.). Plasmid DNA was extracted from the white colonies grown on indicator plates containing 5-bromo-4-chloro-3-indolyl- $\beta$-dgalactopyranoside (X-gal) and isopropyl $\beta$-D-1-thiogalactopyranoside (IPTG) using a PerfectPrep Spin Mini Kit (5 PRIME Inc.) and sent for sequencing. The sequencing services were performed by Genscript (Piscataway, NJ). A Blastn-search was performed in NCBI to identify the species.

\section{Results}

Specificity of primers. Primers PsF7 and PsR7 were designed based on the ITS rDNA sequence of $P$. scribneri (GenBank accession KT873860.1) in comparison with 20 other sequences of eight Pratylenchus spp. A specific 136-bp fragment was expected to be amplified from $P$. scribneri by this primer set. The specificity of primers was tested using confirmed control nematode species shown in Table 1. Excluding P. agilis, a single specific amplicon by the conventional PCR was observed from all three P. scribneri isolates (Ps-p, Ps-t, and Ps-c), whereas no amplification was detected from others, including five Pratylenchus spp., four Heterodera spp., three Meloidogyne spp., one Paratrichodorus spp., and two Globodera spp. The real-time PCR assay produced the same results; no amplification of DNA was derived from other Pratylenchus spp. and other nematode genera, with $\mathrm{Cq}$ values that were not detectable. The $\mathrm{Cq}$ values of the three $P$. scribneri isolates ranged from $26.4 \pm 0.1$ to $28.6 \pm 0.2$. A single melting peak at $81.5^{\circ} \mathrm{C}$ was observed from this real-time PCR, indicating that a single amplicon existed (Fig. 1). $P$. agilis, which is considered as a junior synonym of $P$. scribneri (De Luca et al. 2011; Subbotin et al. 2008), had the same amplification 
results as $P$. scribneri using both conventional PCR and real-time PCR $(\mathrm{Cq}=28.1 \pm 0.1)$. No amplification was observed in nontemplate controls that contained water instead of DNA.

Detection sensitivity of conventional and real-time PCR. The standard curve generated from the data obtained with serial dilutions revealed a high correlation between $\mathrm{Cq}$ values and $\log _{10}$ values of the number of nematodes used for DNA extraction $\left(R^{2}=\right.$ 0.992 , slope $=-3.3, \mathrm{E}=99.1 \%$ ), indicating that the primers were applicable to the real-time PCR assay. Conventional PCR clearly amplified DNA extracted from an equivalent of one-fourth of a nematode, according to the electrophoresis on $2.0 \%$ agarose gel (Fig. 2). The real-time PCR assay successfully detected amplification from DNA extracted from an equivalent of two nematodes down to $1 / 32$ of a nematode, with the $\mathrm{Cq}$ value ranging from $25.4 \pm 0.0$ to $30.6 \pm 0.3$ (Fig. 2). Moreover, the standard curve also showed that the real-time PCR could even detect DNA extracted from the equivalent of $1 / 128$ of a nematode with a $\mathrm{Cq}$ value of $33.6 \pm 0.4$ (Fig. 3). There was always no amplification from nontemplate controls.
Identification and confirmation of $\boldsymbol{P}$. scribneri isolated from infested field samples. The densities of root-lesion nematodes per $200 \mathrm{~g}$ of soil ranged from 20 to 700 (Table 2). The conventional PCR assay with primer set PsF7/PsR7 suggested that 13 of the root-lesion nematodes (from fields F9, F16, and F21 to F31) had the same specific amplification pattern as the three isolates of $P$. scribneri shown in Table 1; therefore, these 13 root-lesion nematodes were identified as P. scribneri (Table 2). Likewise, amplifications were only observed from DNA from fields F9, F16, and F21 to F31 in the real-time PCR assay, with Cq values of $25.7 \pm 0.2$ to $30.0 \pm$ 0.2 , which supported the identification that these root-lesion nematodes were $P$. scribneri. Using primer set Pn-ITS-F2/Pn-ITS-R2 specific for identifying $P$. neglectus (Yan et al. 2013b) and PP5 specific for $P$. penetrans (Mekete et al. 2011), the conventional PCR assay classified the rest of the recovered root-lesion nematodes into two species; 9 were $P$. neglectus (from fields F1 to F9) and 11 were $P$. penetrans (from fields F10 to F20). Additionally, in both PCR assays, nontemplate controls consistently had no amplification. The banding patterns of PCR amplifications using PsF7/PsR7 from

Table 2. Root-lesion nematodes (RLN) collected from 31 fields in different locations in North Dakota and Minnesota used to test species-specific polymerase chain reaction (PCR) assays ${ }^{\mathrm{a}}$

\begin{tabular}{|c|c|c|c|c|c|c|c|c|c|c|}
\hline \multirow[b]{3}{*}{ Field } & \multirow[b]{3}{*}{ Crop } & \multirow[b]{3}{*}{ County, state } & \multirow[b]{3}{*}{ Sampling date } & \multirow[b]{3}{*}{$\mathbf{R L N}^{\mathbf{d}}$} & \multicolumn{4}{|c|}{ PCR assay } & & \\
\hline & & & & & \multicolumn{3}{|c|}{ Conventional $^{b}$} & \multirow{2}{*}{$\frac{\mathrm{RT}(\mathrm{Cq})^{\mathrm{c}}}{\mathrm{Ps}}$} & \multicolumn{2}{|c|}{ Species identity } \\
\hline & & & & & $\overline{\mathbf{P p}}$ & Pn & $\overline{\text { Ps }}$ & & PCR assaye & Sequencing $\mathrm{f}$ \\
\hline $\mathrm{F} 1$ & Potato & Sherburne, MN & 23 June 2015 & 150 & + & - & - & N/A & P. penetrans & $P$ P. penetrans \\
\hline $\mathrm{F} 2$ & Potato & Sherburne, MN & 23 June 2015 & 120 & + & - & - & N/A & $P$. penetrans & P. penetrans \\
\hline F3 & Potato & Sherburne, MN & 23 June 2015 & 700 & + & - & - & $\mathrm{N} / \mathrm{A}$ & P. penetrans & P. penetrans \\
\hline $\mathrm{F} 4$ & Potato & Sherburne, MN & 22 September 2015 & 160 & + & - & - & N/A & P. penetrans & P. penetrans \\
\hline F5 & Potato & Sherburne, MN & 22 September 2015 & 60 & + & - & - & N/A & P. penetrans & P. penetrans \\
\hline F6 & Potato & Sherburne, MN & 25 September 2015 & 20 & + & - & - & N/A & P. penetrans & P. penetrans \\
\hline F7 & Potato & Sherburne, MN & 25 September 2015 & 280 & + & - & - & $\mathrm{N} / \mathrm{A}$ & P. penetrans & $P$. penetrans \\
\hline F8 & Soybean & Sherburne, MN & 21 September 2015 & 130 & + & - & - & N/A & $P$. penetrans & $\mathrm{NI}$ \\
\hline \multirow[t]{2}{*}{ F9 } & Soybean & Sherburne, MN & 21 September 2015 & 125 & + & - & - & N/A & P. penetrans & NI \\
\hline & $\ldots$ & $\ldots$ & $\ldots$ & $\ldots$ & - & - & + & $27.5 \pm 0.1$ & P. scribneri & NI \\
\hline F10 & Sugarbeet & Clay, MN & 25 June 2015 & 300 & - & + & - & N/A & P. neglectus & P. neglectus \\
\hline F11 & Wheat & Ramsey, ND & 17 October 2014 & 180 & - & + & - & N/A & P. neglectus & P. neglectus \\
\hline F12 & Wheat & Nelson, ND & 17 October 2014 & 460 & - & + & - & $\mathrm{N} / \mathrm{A}$ & P. neglectus & P. neglectus \\
\hline F13 & Corn & Ransom, ND & 31 October 2014 & 560 & - & + & - & N/A & P. neglectus & P. neglectus \\
\hline F14 & Corn & Grand Forks, ND & 19 September 2015 & 160 & - & + & - & N/A & $P$. neglectus & P. neglectus \\
\hline F15 & Corn & Sargent, ND & 29 May 2015 & 25 & - & + & - & N/A & P. neglectus & NI \\
\hline \multirow[t]{2}{*}{ F16 } & Corn & Richland, ND & 2 October 2015 & 20 & - & + & - & N/A & P. neglectus & P. neglectus \\
\hline & $\ldots$ & $\ldots$ & $\ldots$ & $\ldots$ & - & - & + & $29.7 \pm 0.4$ & P. scribneri & P. scribneri \\
\hline F17 & Soybean & Griggs, ND & 4 October 2015 & 160 & - & + & - & N/A & P. neglectus & P. neglectus \\
\hline F18 & Soybean & Cass, ND & 4 October 2015 & 70 & - & + & - & N/A & $P$. neglectus & NI \\
\hline F19 & Soybean & Cass, ND & 4 October 2015 & 45 & - & + & - & N/A & P. neglectus & NI \\
\hline $\mathrm{F} 20$ & Soybean & Sherburne, MN & 27 October 2015 & 50 & - & + & - & N/A & P. neglectus & NI \\
\hline $\mathrm{F} 21$ & Potato & Sargent, ND & 22 April 2015 & 180 & - & - & + & $26.9 \pm 0.1$ & P. scribneri & P. scribneri \\
\hline $\mathrm{F} 22$ & Potato & Sargent, ND & 22 April 2015 & 450 & - & - & + & $27.3 \pm 0.2$ & P. scribneri & NI \\
\hline $\mathrm{F} 23$ & Potato & Sargent, ND & 22 April 2015 & 360 & - & - & + & $25.7 \pm 0.2$ & P. scribneri & NI \\
\hline F24 & Soybean & Richland, ND & 31 October 2014 & 175 & - & - & + & $27.0 \pm 0.2$ & P. scribneri & P. scribneri \\
\hline $\mathrm{F} 25$ & Soybean & Traill, ND & 4 October 2015 & 50 & - & - & + & $28.0 \pm 0.2$ & P. scribneri & NI \\
\hline F26 & Barley & Nelson, ND & 17 October 2014 & 100 & - & - & + & $29.4 \pm 0.1$ & P. scribneri & P. scribneri \\
\hline $\mathrm{F} 27$ & Corn & Dickey, ND & 30 October 2014 & 300 & - & - & + & $26.7 \pm 0.4$ & P. scribneri & P. scribneri \\
\hline F28 & Corn & Sargent, ND & 29 May 2015 & 114 & - & - & + & $29.0 \pm 0.4$ & P. scribneri & P. scribneri \\
\hline F29 & Corn & Dickey, ND & 29 May 2015 & 725 & - & - & + & $30.0 \pm 0.2$ & P. scribneri & P. scribneri \\
\hline F30 & Corn & Stutsman, ND & 24 September 2015 & 160 & - & - & + & $28.5 \pm 0.2$ & P. scribneri & P. scribneri \\
\hline F31 & Field pea & Wells, ND & 9 July 2015 & 20 & - & - & + & $26.8 \pm 0.1$ & P. scribneri & P. scribneri \\
\hline
\end{tabular}

a Species was identified by PCR assays and sequencing.

${ }^{\mathrm{b}}$ RLN density. Species-specific primers of conventional PCR for Pratylenchus penetrans (Pp), P. neglectus (Pn), and P. scribneri (Ps) are PP5 (Mekete et al. 2011), Pn-ITS-F2/Pn-ITS-R2 (Yan et al. 2013b), and PsF7/PsR7 (this study), respectively; + or - indicates that the target-specific amplicons are present or absent, respectively, using conventional PCR with species-specific primers.

${ }^{c}$ Real-time (RT) quantification cycle (Cq). Primer set PsF7/PsR7 (this study) for P. scribneri identification was used in RT-PCR assay. N/A indicates no amplification was detected by RT-PCR and data were presented as mean \pm standard deviation.

d Number of root-lesion nematodes per $200 \mathrm{~g}$ of soil.

e Species were identified based on the species-specific PCR assays. Pratylenchus penetrans and $P$. neglectus were identified by published primers and $P$. scribneri by the primers developed in this study.

${ }^{\mathrm{f}}$ Species were identified based on the Blast results of sequences of D2-D3 expansion region of 28s ribosomal RNA (rRNA) or internal transcribed spacer rDNA; NI indicates that no information was available. 
DNA from fields F1 to F8, F11 to F15, F17 to F18, and F21 to F27 are shown in Figure 4. Sequence information of five samples (F1, F2, F3, F12, and F21) in both D2-D3 of 28s rRNA were obtained while, due to sequencing quality, sequence information of six samples (F4, F5, F6, F7, F10, and F16) in the ITS rDNA region and sequences of 11 samples (F11, F13, F14, F17, F24, and F26 to 31) in the D2-D3 region of 28S rRNA were obtained to verify the species identity (Supplementary Table S1). The Blastn search presented consistent results with the species identity determined by PCR assays (Table 2). These results indicate a successful discrimination of $P$. scribneri from $P$. penetrans and $P$. neglectus extracted from field samples using conventional and real-time PCR assays with the species-specific primer set PsF7/PsR7. Even more, $P$. scribneri also could be identified either when mixed with two other Pratylenchus

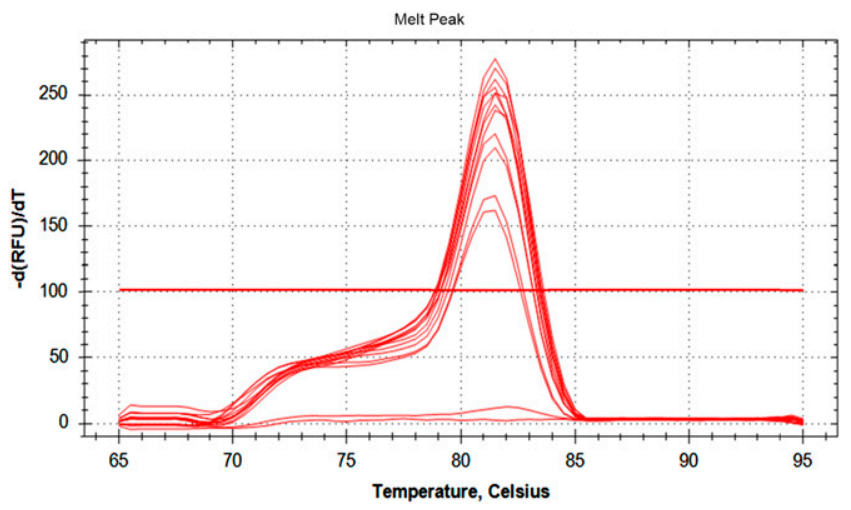

Fig. 1. Melting curve of Pratylenchus scribneri-specific amplicons with melting temperature at $81.5^{\circ} \mathrm{C}$.

\begin{tabular}{|c|c|c|c|c|c|c|c|c|}
\hline DNA Serial dilutions & \multirow{3}{*}{$\mathrm{M}$} & $1: 1$ & $1: 2$ & $1: 4$ & $1: 8$ & $1: 16$ & $1: 32$ & NTC \\
\hline Number of nematodes & & 2 & 1 & $1 / 2$ & $1 / 4$ & $1 / 8$ & $1 / 16$ & 0 \\
\hline Real-time PCR (Cq) & & $\begin{array}{l}25.4 \\
\pm 0.0\end{array}$ & $\begin{array}{l}26.5 \\
\pm 0.1\end{array}$ & $\begin{array}{l}27.3 \\
\pm 0.1\end{array}$ & $\begin{array}{l}28.2 \\
\pm 0.0\end{array}$ & $\begin{array}{l}29.4 \\
\pm 0.2\end{array}$ & $\begin{array}{c}30.6 \\
\pm 0.3\end{array}$ & N/A \\
\hline \multirow[t]{2}{*}{ Conventional PCR } & $\overline{3}$ & 2 & 2 & 2 & 23 & $=3$ & & $=$ \\
\hline & $\equiv$ & - & - & s. & & & & \\
\hline
\end{tabular}

Fig. 2. Comparison of amplification sensitivity between conventional polymerase chain reaction (PCR) and real-time PCR. DNA was extracted from two nematodes and sequential two-fold serial dilutions were used. Quantification cycle $(\mathrm{Cq})$ value was presented as the mean \pm standard deviation of three replicates. $M=100 \mathrm{bp}$ DNA ladder (Promega Corp.), N/A = not amplified, and NTC $=$ nontemplate control.

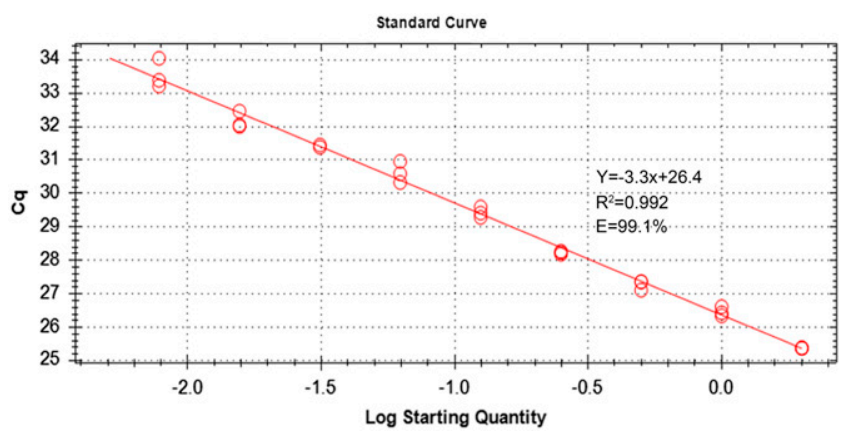

Fig. 3. Standard curve of the real-time polymerase chain reaction assay for Pratylenchus scribneri: quantification cycle number $(\mathrm{Cq})$ plotted against the log of the number of individuals of $P$. scribneri by sequential twofold dilutions $(2,1,1 / 2,1 / 4$, $1 / 8,1 / 16,1 / 32,1 / 64$, and 1/128). Experiments were repeated in triplicate. Circles represent individual values for each dilution and replicate. spp. (P. neglecuts and $P$. penetrans) or from nematode suspensions with mixed nematode populations isolated from field samples by the conventional PCR assay (Fig. 5; Supplementary Fig. S3.). Additionally, $P$. scribneri was found in seven counties (Richland, Sargent, Nelson, Traill, Dickey, Stutsman, and Wells) in North Dakota and one county in Minnesota (Sherburne) on five crops (potato, soybean, barley, corn, and field pea). P. neglectus was distributed in seven counties in North Dakota (Ramsey, Nelson, Grand Forks, Sargent, Richland, Griggs, and Cass) and two counties in Minnesota (Clay and Sherburne). P. penetrans was found in one County (Sherburne) in Minnesota. Moreover, it was noted that two field samples had mixed populations of root-lesion nematodes. Field F9 from Sherburne County, MN had mixed populations of $P$. penetrans and $P$. scribneri while field F16 from Richland County, ND had a mixture of $P$. neglectus and $P$. scribneri.

\section{Discussion}

The root-lesion nematode species $P$. scribneri was specifically detected from various field samples of root-lesion nematodes collected from North Dakota and Minnesota using conventional and real-time PCR assays developed in this study. The specificity of PCR assays for $P$. scribneri detection was demonstrated by testing with template DNA from 11 isolates of Pratylenchus spp. and 11 isolates of nonPratylenchus spp. The assay for $P$. scribneri identification was highly reliable, which was confirmed by sequencing two genomic regions. The PCR assays were also sensitive, because the conventional PCR was able to detect an equivalent of $1 / 4$ of a nematode and realtime PCR could detect an equivalent of $1 / 128$ of a nematode. To our knowledge, this is the first report of P. scribneri identification by

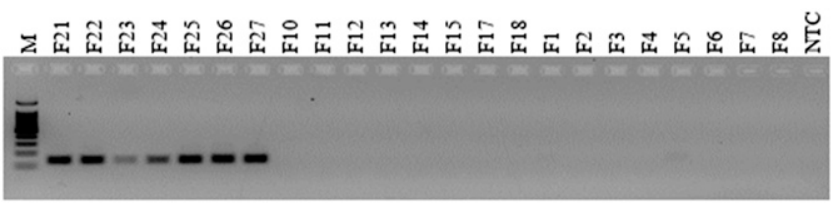

Fig. 4. Detection of Pratylenchus scribneri by conventional polymerase chain reaction (PCR) using primer set PsF7/PsR7. M represents 100-bp DNA ladder (Promega Corp.) and NTC stands for the nontemplate control, with sterilized double-distilled $\mathrm{H}_{2} \mathrm{O}$ instead of DNA in the PCR.

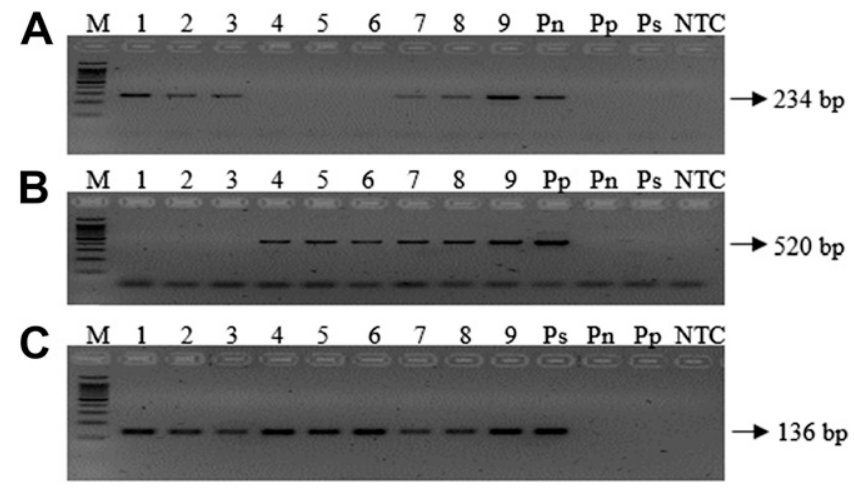

Fig. 5. Identification of Pratylenchus scribneri from DNA extracted from artificial mixture of $P$. scribneri and other Pratylenchus spp. by conventional polymerase chain reaction (PCR) using species-specific primers. A, Amplified with P. neglectusspecific primer set Pn-ITS-F2/Pn-ITS-R2 (234 bp). B, Amplified with $P$. penetransspecific primer set PP5 (520 bp). C, Amplified with $P$. scribneri-specific primer set PsF7/PsR7 (136 bp). M represents 100-bp DNA ladder (Promega Corp.). Lanes 1 to 3 , DNA was extracted from a mixture of single $P$. scribneri and $P$. neglectus nematodes; lanes 4 to 6 : DNA was extracted from a mixture of single $P$. scribneri and $P$. penetrans nematodes; lanes 7 to 9 : DNA was extracted from a mixture of single $P$. scribneri, $P$. neglectus, and $P$. penetrans nematodes; lane $P$ n, positive control of $P$. neglectus; lane $\mathrm{Pp}$, positive control of $P$. penetrans; lane Ps, positive control of $P$. scribneri; and NTC, nontemplate control, with sterilized double-distilled $\mathrm{H}_{2} \mathrm{O}$ instead of DNA in the PCR. 
real-time PCR assay using species-specific primers designed from ITS rDNA.

The species-specific primer used in this study was designed from ITS rDNA that was considered to be variable regions of rRNA among genera and species and frequently used in nematode species differentiation, compared with $28 \mathrm{~S}$ rRNA or $18 \mathrm{~S}$ rRNA that was more conserved through evolution (De Luca et al. 2011; Subbotin and Moens 2006). Many reports have demonstrated that ITS rDNA sequences vary among different Pratylenchus spp. (De Luca et al. 2011; Uehara et al. 1998a,b, 1999; Waeyenberge et al. 2000), indicating a high potential for success in using this region to differentiate $P$. scribneri from other Pratylenchus spp. Previously, Setterquist et al. (1996) used a species-specific amplification targeting the major sperm protein gene (MSP) to differentiate $P$. scribneri from $P$. penetrans. However, gene sequence information of MSP in Pratylenchus spp. is rare, making it hard to predict the ability of primers from MSP gene to distinguish $P$. scribneri from other Pratylenchus spp. Later on, Al-Banna et al. (2004) and Mekete et al. (2011) reported the specific detection of $P$. scribneri from other Pratylenchus spp. using specific primers designed from $28 \mathrm{~S}$ rRNA and ITS rDNA. Nevertheless, reported primers failed to specifically differentiate $P$. scribneri from P. neglectus or P. penetrans found in North Dakota and Minnesota. The possible reason could be the sequence variation at the binding sites of the reported primers between the isolates of Pratylenchus spp. collected by Al-Banna et al. (2004), Mekete et al. (2011), and by us in this study. Waeyenberge et al. (2009) also mentioned that the reported primer set PP1/PP2 developed by Uehara et al. (1998a) was not capable for detecting all $P$. penetrans isolates they collected. In this study, the in silico analysis indicated that our designed primer set was specific for $P$. scribneri, including the isolates collected from the United States and China. Actual experiments showed that our developed species-specific PCR assays successfully discriminated P. scribneri isolates of North Dakota, Florida, and Ohio (Table 1) from $P$. crenatus, $P$. zeae, $P$. thornei, $P$. neglectus, $P$. penetrans, and other non-Pratylenchus spp. The PCR assays also could specifically differentiate all populations of $P$. scribneri from $P$. neglectus and $P$. penetrans collected from different fields in North Dakota and Minnesota (Table 2; Fig. 4). Furthermore, $P$. scribneri was specifically detected from either artificial mixtures of $P$. penetrans and P. neglectus (Fig. 5) or infested fields with mixed populations of Pratylenchus spp. such as fields F9 and F16, which also had $P$. penetrans and $P$. neglectus (Table 2), and from nematode suspensions containing free-living nematodes and other plant-parasitic nematodes.

Both conventional and real-time PCR assays were used in this study. Conventional PCR with species-specific primers have been described (Castillo and Volvas 2007) but not all of those primers can be directly used in a real-time PCR because of the detection of nonspecific amplification caused by greater amplification sensitivity of real-time PCR (Yan et al. 2013b). Our designed species-specific primers could be used in conventional PCR assays for species identification and also were applicable for real-time PCR assays, demonstrated by high E $(99.1 \%)$ and great $R^{2}(0.99)$ obtained from the standard curve in the real-time PCR assay. More than speciesspecific detection, a real-time PCR assay also provides detailed information of primer performance in the PCR detection. In this study, we also conducted experiment on the detection sensitivity of PCR assays, referring to the minimum number of nematodes in a DNA extraction that could be detectable using serial dilutions. Practically, a single nematode could be used in species identification using these molecular detection methods. These findings are consistent with previous findings (Madani et al. 2005; Mokrini et al. 2013; Toyota et al. 2008; Yan et al. 2012, 2013a,b). Additionally, real-time PCR was more sensitive than conventional PCR and could amplify DNA extracts containing an equivalent of $1 / 128$ of a nematode. The sensitivity of our real-time PCR assay was comparable to other reported assays. Yan et al. (2012, 2013b) quantified $P$. thornei and $P$. neglectus from DNA extracts of soil and found that as little as 0.5 nematode per $0.5 \mathrm{~g}$ of soil could be detectable using real-time PCR. Mokrini et al. (2013) detected a single nematode of $P$. penetrans when mixed with
80 individuals of $P$. thornei. Studies with other nematode species such as cyst nematode and root-knot nematodes also found that a single nematode could be used for nematode species detection by real-time PCR assay (Madani et al. 2005; Toyota et al. 2008). In a sensitivity analysis for $H$. filipjevi detection, Peng et al. (2013) detected 1/160 of a juvenile, $1 / 5,120$ of a female, and $5 \times 10^{-4}$ of a cyst by a speciesspecific sequence-characterized amplified region PCR assay.

It was noted in this study that $P$. agilis yielded the same amplification pattern as $P$. scribneri in both conventional PCR and real-time PCR assays. One of the root-lesion nematode specimens (Ps-P) collected from Cogswell, Sargent County, ND was identified as $P$. scribneri according to both morphological data and molecular analysis (Yan et al. 2016b) and was used as control in this study. In $1968, P$. agilis was proposed to be a close relative to $P$. scribneri according to similar stylet length, body striations, and lower but more massive head structure (Thorne and Malek 1968). Later on, Handoo and Golden (1989) found no significant morphological differences between $P$. agilis and $P$. scribneri, including the number of labial annuli, the enface view, and the shape and location of the amphidial openings and female tail. Hernández et al. (2000) also found a similar face view observed by scanning electron microscopy. In addition to that, the isozyme pattern and ITS rDNA gel band position showed that these two species are synonymous. Furthermore, the results of DNA sequencing such as sequence analysis of the D2-D3 expansion region of $28 \mathrm{~S}$ rRNA and ITS rDNA strongly revealed that $P$. agilis and $P$. scribneri are the same species (De Luca et al. 2011; Subbotin et al. 2008). Our results also suggested that $P$. agilis and $P$. scribneri are analogous species.

The PCR assays with species-specific primers developed in this study provide a rapid and reliable detection and identification of $P$. scribneri using a single nematode. The assays are suitable for use in diagnostic laboratories and detection of field infestations with this nematode species. This study will also help in further developing a real-time PCR assay to detect and quantify $P$. scribneri directly from DNA extracts of field soils.

\section{Acknowledgments}

This research was supported by Northern Plains Potato Growers Association, Minnesota Area II Potato Research and Promotion Council, North Dakota Soybean Council, North Dakota Corn Utilization Council, the United States Department of Agriculture (USDA), and the North Dakota Department of Agriculture. We thank A. Plaisance, A. Upadhaya, and I. Chowdhury for collecting nematodes; growers who allowed us to collect soil samples from their properties; and A. Skantar at the USDA Agricultural Research Service Nematology Laboratory (Beltsville, MD), R. Smiley at Oregon State University, B. Nelson at North Dakota State University, and S. Chen at the University of Minnesota for providing nematodes or DNA of control species.

\section{Literature Cited}

Al-Banna, L., Ploeg, A. T., Williamson, V. M., and Kaloshian, I. 2004 Discrimination of six Pratylenchus species using PCR and species-specific primers. J. Nematol. 36:142-146.

Castillo, P., and Volvas, N. 2007. Pratylenchus (Nematoda: Pratylenchidae): Diagnosis, Biology, Pathogenicity and Management. Nematology Monographs and Perspectives, Vol. 6. Brill, Leiden, The Netherlands. doi:10.1163/ ej.9789004155640.i-523

Chen, S. Y., Sheaffer, C. C., Wyse, D. L., Nickel, P., and Kandel, H. 2012. Plantparasitic nematode communities and their associations with soil factors in organically farmed fields in Minnesota. J. Nematol. 44:361-369.

Crow, R. V., and MacDonald, D. H. 1978. Phytoparasitic nematodes adjacent to established strawberry plantations. J. Nematol. 10:204-207.

De Luca, F., Reyes, A., Troccoli, A., and Castillo, P. 2011. Molecular variability and phylogenetic relationships among different species and populations of Pratylenchus (Nematoda: Pratylenchidae) as inferred from the analysis of the ITS rDNA. Eur. J. Plant Pathol. 130:415-426.

Donn, S., Griffiths, B. S., Neilson, R., and Daniell, T. J. 2008. DNA extraction from soil nematodes for multi-sample community studies. Appl. Soil Ecol. 38:20-26.

Fatima, F., Chaudhary, I., Ali, J., Rastogi, S., and Pathak, N. 2011. Microbial DNA extraction from soil by different methods and its PCR amplification. Biochem. Cell Arch. 11:85-90.

Handoo, Z. A., and Golden, A. M. 1989. A key and diagnostic compendium to the species of the genus Pratylenchus Filipjev, 1936 (lesion nematodes). J. Nematol. 21:202-218.

Hernández, M., Jordana, R., Goldaracena, A., and Pinochet, J. 2000. SEM observations of nine species of the genus Pratylenchus Filipjev, 1936 (Nematoda: Pratylenchidae). J. Nematode Morphol. Syst. 3:165-174. 
Holgado, R., Oppen Skau, K. A., and Magnusson, C. 2009. Field damage in potato by lesion nematode Pratylenchus penetrans, its association with tuber symptoms and its survival in storage. Nematol. Mediterr. 37:25-29.

Jenkins, W. R. 1964. A rapid centrifugal-flotation technique for separating nematodes from soil. Plant Dis. Rep. 48:692.

Jones, J. T., Haegeman, A., Danchin, E. G. J., Gaur, H. S., Helder, J., Jones, M. G. K., Kikuchi, T., Manzanilla-López, R., Palomares-Rius, J. E., Wesemael, W. M. L., and Perry, R. N. 2013. Top 10 plant-parasitic nematodes in molecular plant pathology. Mol. Plant Pathol. 14:946-961.

Jones, M. G. K., and Fosu-Nyarko, J. 2014. Molecular biology of root lesion nematodes (Pratylenchus spp.) and their interaction with host plants. Ann. Appl. Biol. 164:163-181.

Kumari, S., and Subbotin, S. A. 2012. Molecular characterization and diagnostic of stubby root and virus vector nematodes of the family Truchodoridae (Nametode: Triplonchida) using ribosomal RAN genes. Plant Pathol. 61: 1021-1031.

Machado, A., Ferraz, L., and de Oliveira, C. M. G. 2007. Development of a species-specific reverse primer for the molecular diagnostic of Pratylenchus brachyurus. Nematropica 37:249-258.

Madani, M., Subbotin, S. A., and Moens, M. 2005. Quantitative detection of the potato cyst nematode, Globodera pallida, and the beet cyst nematode, Heterodera schachtii, using real-time PCR with SYBR green I dye. Mol. Cell. Probes 19:81-86.

Mekete, T., Reynolds, K., Lopez-Nicora, H. D., Gray, M. E., and Niblack, T. L. 2011. Distribution and diversity of root-lesion nematode (Pratylenchus spp.) associated with Miscanthus $\times$ giganteus and Panicum virgatum used for biofuels, and species identification in a multiplex polymerase chain reaction. Nematology 13:673-686.

Mokrini, F., Waeyenberge, L., Viaene, N., Abbad Andaloussi, F., and Moens, M. 2013. Quantitative detection of the root-lesion nematode, Pratylenchus penetrans, using qPCR. Eur. J. Plant Pathol. 137:403-413.

Nelson, B. D., Bolton, M. D., Lopez-Nicora, H. D., Niblack, T. L., and del Rio Mendoza, L. 2012. First confirmed report of sugar beet cyst nematode, Heterodera schachtii, in North Dakota. Plant Dis. 96:772.

Oliveira, C. M. G., Monteiro, A. R., and Blok, V. C. 2011. Morphological and molecular diagnostics for plant-parasitic nematodes: Working together to get the identification done. Trop. Plant Pathol. 36:65-73.

Peng, H., Qi, X., Peng, D., Long, H., He, X., Huang, W., and He, W. 2013. Sensitive and direct detection of Heterodera filipjevi in soil and wheat roots by species-specific SCAR-PCR assays. Plant Dis. 97:1288-1294.

Pinochet, J., Cenis, J. L., Fernández, C., Doucet, M., and Marull, J. 1994. Reproductive fitness and random amplified polymorphic DNA variation among isolates of Pratylenchus vulnus. J. Nematol. 26:271-277.

Plaisance, A., and Yan, G. P. 2015. Comparison of two nematode extraction techniques. Page 120 in Abstr. 54th Annu. Meet. Soc. Nematol. East Lansing, MI.

Sato, E., Min, Y. Y., Shirakashi, T., Wada, S., and Toyota, K. 2007. Detection of the root-lesion nematode, Pratylenchus penetrans (Cobb), in a nematode community using real-time PCR. Jpn. J. Nematol. 37:87-92.

Setterquist, R. A., Smith, G. K., Jones, R., and Fox, G. E. 1996. Diagnostic probes targeting the major sperm protein gene that may be useful in the molecular identification of nematodes. J. Nematol. 28:414-421.

Smiley, R. W., Whittaker, R. G., Gourlie, J. A., and Easley, S. A. 2005. Suppression of wheat growth and yield by Pratylenchus neglectus in the Pacific Northwest. Plant Dis. 89:958-968.

Subbotin, S. A., and Moens, M. 2006. Molecular taxonomy and phylogeny. Pages 33-58 in: Plant Nematology. R. N. Perry and M. Moens, eds. CABI Publishing, Wallingford, UK.

Subbotin, S. A., Ragsdale, E. J., Mullens, T., Roberts, P. A., Mundo-Ocampo, M., and Baldwin, J. G. 2008. A phylogenetic framework for root lesion nematodes of the genus Pratylenchus (Nematoda): Evidence from 18S and D2-D3 expansion segments of $28 \mathrm{~S}$ ribosomal RNA genes and morphological characters. Mol. Phylogenet. Evol. 48:491-505.

Tanha Maafi, Z., Subbotin, S. A., and Moens, M. 2003. Molecular identification of cyst-forming nematodes (Heteroderidae) from Iran and a phylogeny based on the ITS sequences of rDNA. Nematology 5:99-111.

Taylor, D. P., Anderson, R. V., and Haglund, W. A. 1958. Nematodes associated with Minnesota crops. I. Preliminary survey of nematodes associated with alfalfa, flax, peas, and soybeans. Plant Dis. Rep. 42:195-198.

Taylor, D. P., and Schleder, E. G. 1959. Nematodes associated with Minnesota crops. II. Nematodes associated with corn, barley, oats, rye, and wheat. Plant Dis. Rep. 43:329-333.

Thorne, G., and Malek, R. B. 1968. Nematode of the North Great Plains. I Tylenchida. S. D. Agric. Exp. Stn. Tech. Bull. 31

Toyota, J. B., Shirakashi, T., Sato, E., and Wada, S. 2008. Development of a realtime PCR method for the potato-cyst nematode Globodera rostochiensis and the root-knot nematode Meloidogyne incognita. J. Plant Nutr. Soil Sci. 54 $72-76$

Uehara, T., Kushida, A., and Momota, Y. 1999. Rapid and sensitive identification of Pratylenchus spp. using reverse dot blot hybridization. Nematology 1: 549-555.

Uehara, T., Mizukubo, T., Kushida, A., and Momota, Y. 1998a. Identification of Pratylenchus penetrans (Cobb) by PCR using ITS-based species-specific primers. Jpn. J. Nematol. 28:1-7.

Uehara, T., Mizukubo, T., Kushida, A., and Momota, Y. 1998b. Identification of Pratylenchus coffeae and P. loosi using specific primers for PCR amplification of ribosomal DNA. Nematologica 44:357-368.

Waeyenberge, L., Moens, M., Pinochet, J., and Vrain, T. C. 2000. Molecular characterization of Pratylenchus species using rDNA restriction fragment length polymorphisms. Nematology 2:135-142.

Waeyenberge, L., Viaene, N., and Moens, M. 2009. Species-specific duplex PCR for the detection of Pratylenchus penetrans. Nematology 11:847-857.

Yan, G. P., Khan, M. F., Huang, D., Lai, X., and Handoo, Z. A. 2016a. First report of the stubby root nematode Paratrichorodorus allius on sugar beet in Minnesota. Plant Dis. 100:1022.

Yan, G. P., Plaisance, A., Huang, D., Gudmestad, N. C., and Handoo, Z. A. 2016b. First report of the root-lesion nematode Pratylenchus scribneri infecting potato in North Dakota. Plant Dis. 100:1023.

Yan, G. P., Plaisance, A., Huang, D., Liu, Z., Chapara, V., and Handoo, Z. A. 2016c. First report of the root-lesion nematode Pratylenchus neglectus on wheat (Triticum aestivum) in North Dakota. Plant Dis. 100:1794.

Yan, G. P., Plaisance, A., Huang, D., Upadhaya, A., Gudmestad, N. C., and Handoo, Z. A. 2016d. First report of the stubby root nematode Paratrichodorus allius on potato in North Dakota. Plant Dis. 100:1247.

Yan, G. P., Plaisance, A., and Ye, W. 2015. Plant-parasitic nematodes on field crops in Southeastern and Northeastern North Dakota. American Phytopathological Society Annual Meeting, Pasadena, CA.

Yan, G. P., Smiley, R. W., and Okubara, P. A. 2012. Detection and quantification of Pratylenchus thornei in DNA extracted from soil using real-time PCR Phytopathology 102:14-22.

Yan, G. P., Smiley, R. W., Okubara, P. A., and Skantar, A. M. 2013a. Speciesspecific PCR assay for differentiating Heterodera filipjevi and $H$. avenae. Plant Dis. 97:1611-1619.

Yan, G. P., Smiley, R. W., Okubara, P. A., Skantar, A. M., and Reardon, C. L. 2013b. Developing a real-time PCR assay for detection and quantification of Pratylenchus neglectus in soil. Plant Dis. 97:757-764.

Yan, G. P., Smiley, R. W., Skantar, S. A., Easley, A., Sheedy, J. G., and Thompson, A. L. 2008. Detection and discrimination of Pratylenchus neglectus and $P$. thornei in DNA extracts from soil. Plant Dis. 92:1480-1487.

Yu, Y.-T., Liu, H.-L., Zhu, A.-G., Zhang, G., Zeng, L.-B., and Xue, S. D. 2012 A review of root lesion nematode: Identification and plant resistance. Adv. Microbiol. 2:411-416. 